\title{
Effect of Smoke Solution of Sage (Salvia officinalis L.) on Root and Shoot Growth of Grass Pea (Lathyrus sativus L.)
}

\author{
Cennet Yaman ${ }^{1 a^{*}}$, Uğur Basaran ${ }^{1 b}$ \\ ${ }^{1}$ Field Crops Department, Faculty of Agriculture, Bozok University, 66900 Yozgat, Turkey \\ *Corresponding author
}

A R T I C L E I N F O
Research Article
Received : 16/11/2018
Accepted : 15/02/2019

Keywords:

Smoke solution

Sage

Grass pea

Root length

Shoot length

\begin{abstract}
A B S T R A C T
In this study, the effect of different concentrations of smoke solution derived from sage (Salvia officinalis L.) on root and shoot growth of grass pea (Lathyrus sativus L.) was investigated in pots, in petri dishes (in vivo) and in vitro conditions. Smoke solution was obtained from hookah method and different concentrations $(25 \%, 50 \%, 75 \%, 100 \%)$ were prepared by diluting the stock solution with distilled water and, distilled water was used as control. Solutions were used starting water of petri and perlite media and to prepare MS0 for in vitro condition. Nodal segments of grass pea seedlings as explants were cultured on MS0 medium in vitro. Plant nutrients, antioxidants, organic or inorganic chemicals, and plant growth regulators are commonly used for plant development both in vivo and in vitro. However, their use has risks in terms of economic costs as well as nature, environment and human health. Therefore, use of naturally derived chemicals in these applications has great advantages. Observations for in vivo conditions were determinate after 7 days from sowing and 15 days after in vitro culture. The longest root length $(6.089 \mathrm{~cm})$ was determined in $75 \%$ smoke solution of sage and, while the longest shoot length $(3.026 \mathrm{~cm})$ was obtained from $100 \%$ smoke solution of sage on petri media. In perlite media, the highest root and shoot length were observed in pure water (control). In vitro conditions, although shoot formation was above $85 \%$ in all applications, root formation was under $33 \%$. The shortest shoot length was obtained from smoke solutions of $100 \%(5.02 \mathrm{~cm})$, the longest shoot length was obtained from $25 \%$ and $75 \%$ concentrations of smoke solution, respectively 8.35 and $8.94 \mathrm{~cm}$.
\end{abstract}

\section{Introduction}

Grass pea (Lathyrus sativus L.) is annual and herbaceous legume rich in protein belonging to Fabaceae family. It is tolerant to drought, moderate to salinity, many diseases and pests (Campbell 1997). Moreover, It can successfully grow in low fertility soils and drought conditions with very low input requirements (Croft et al., 1999, Abd-El Moneim et al., 2000). Because of these features, grass pea has begun to gain importance again in recent years. Especially, it is seen as one of the important plants from the point of sustainable agriculture and effects of global climate change (Kumar et al., 2011). Although grass pea can germinate in a short time in laboratory, its germination in field does not occur before 14-15 days even under in suitable conditions. If grass pea is sown in the spring, harvest period varies between 85-110 days depending on genotype (Basaran et al., 2016). Therefore, it is of great importance to rapid germination and seedling growth in terms of yield for this plant that has a short vegetation period.

In recent years, effects of smoke solutions on germination and seedling growth of different plants were investigated and, it showed positive effect on about 1200 species (Dixon et al., 2009). Effect of components in smoke on germination was first introduced by De Lange and Boucher (1990), and then intensive studies have been performed in this regard. Smoke contains hundreds of compounds. It has been reported that the effect on germination results especially from butenolide (3-methyl2Hfuro [2,3-c] pyran-2-one) (Van Staden et al., 2004). Temperature rise, rapid mineralization and effects of components in ash were also investigated in order to explain the effects of smoke solutions on germination. Smoke solutions are effective on seedling growth and breaking dormancy. It also encourages root development and flowering (Taylor and Van Staden, 1996). Ghebrehiwot et al. (2012) found that seeds treated with smoke solution had longer roots and shoots, but this effect altered with among species and also differed with temperature application. Smoke solutions which contained active substances were obtained by burning proteins, plants etc., and its effects on germination of many plant seeds were examined (Flematti et al., 2004, Light et al., 2005, 
Jain et al., 2006, Flematti et al., 2007, Kepczynski et al., 2010). It was reported that smoke, smoky water, active substance (butenolide etc.) had different effects on germination, shoot and root development for each species and variety (Downes et al., 2010).

In this study, effect of the smoke solution derived from sage (Salvia officinalis L.) on shoot and root development of grass pea (Lathyrus sativus L.) was investigated in pots and petri. In addition, shoot and root formation frequency, number of node, number of branch and plant weight of grass pea were monitored in vitro conditions.

\section{Materials and Methods}

This study was carried out at Laboratory of Field Crops Department, Faculty of Agriculture, Bozok University, Yozgat.

Seeds of variety 'Gurbuz-2001' of grass pea (Lathyrus sativus. L.) were obtained from Faculty of Agriculture, Bozok University. In this study, mature seeds were used for germination in pots and Petri dishes. Nodal segments were also used as explant's source for direct shoot organogenesis.

Preparation of smoke solution (stock): Smoke solutions obtained by burning aerial parts of sage (Salvia officinalis L.) according to Van Staden et. al. (2004) and Ghebrehiwot et al. (2012) with some modifications. The water pipe system (nargile) was used for this process and negative pressure was provided with compressor. The aerial parts dried of $10 \mathrm{~g}$ sage were burned. And, smoke was completely collected through 1 liter of water. The stock solution was filtered through a rough filter paper. The stock solution was diluted with distilled water, to prepare four different concentrations of solution $(100 \%, 75 \%, 50 \%$, $25 \%)$ and, distilled water was used as a control.

Pot experiment: Fifteen seeds of grass pea were sown at a dept of $3 \mathrm{~cm}$ in pots $(10 \times 10 \mathrm{~cm})$ filled with perlite. After sowing, first irrigation was made with solutions, and for next irrigations, distilled water was used. The pots were conducted in laboratory conditions $\left(20-25^{\circ} \mathrm{C}\right)$, daylight. Each treatment was repeated 3 times. Measurements of seedling, root and shoot development were made about on 7 th day after sowing.

Petri experiment: The seed surfaces were sterilized in $20 \%$ sodium hypochlorite (ACE, Turkey commercial $\mathrm{NaOCl}$ was used as a stock in the sterilization process, $5 \%$ $\mathrm{NaOCl}$ ) prior to the germination test (Subaşı and Güvensen 2010). Twenty five seeds were placed on filter paper in $100 \times 10 \mathrm{~mm}$ Petri dishes and, each treatment was repeated 4 times. Each petri was irrigated with $6 \mathrm{ml}$ of stock solutions. Then, the seeds were incubated at $24 \pm 2{ }^{\circ} \mathrm{C}$ for 16 hours light and $8 \mathrm{~h}$ dark conditions at the climate chamber for germination. At the end of 7 th days, average lengths of shoot and root were determined.

In vitro experiment: The seed surfaces were sterilized
$20 \mathrm{~min}$ in $20 \%$ sodium hypochlorite. After sterilization, the seeds were rinsed 3-4 times with sterile distilled water. The sterilized seeds were cultured in MS mineral salts and vitamins (Murashige and Skoog 1962) containing 0.64\% agar (Duchefa) without any growth regulators (MS0) in sterile magenta incubated at $24 \pm 2^{\circ} \mathrm{C}$ in $16 \mathrm{~h}$ photoperiod for seedling growth. Seven days after sowing, single nodal segment of seedlings was dissected under aseptic conditions and used as explant. In the experiments, MS medium containing $3 \%$ sucrose and $0.64 \%$ agar were used. The media were prepared using distilled water (control) and 4 different concentrations $(25 \%, 50 \%, 75 \%, 100 \%)$ of smoke solutions. The $\mathrm{pH}$ of the media were adjusted to 5.8 with $1 \mathrm{M} \mathrm{HCl}$ or $1 \mathrm{M} \mathrm{NaOH}$. All the culture media were sterilized by autoclaving at $121^{\circ} \mathrm{C}, 118 \mathrm{kPa}$ pressure for 20 min. Five explant was put in magenta and, incubated at $24 \pm 2^{\circ} \mathrm{C}$ under $16 / 8 \mathrm{~h}$ light/dark (3000 lux) for shoot initiation. Each treatment was repeated four times. At the end of 15th day, rate of shoot formation (\%), rate of root formation (\%), shoot length/plant $(\mathrm{cm})$, fresh plant weight/plant (mg), number of nod/plant and explant rate of lateral branch formation (\%), number of lateral branch/plant were determined.

All data were subjected to analysis of variance (ANOVA) and the means were compared with Duncan's multiple range tests. The statistical analysis was performed using SPSS 13.0 package program. Data given as percentages were subjected to arcsine transformation (Snedecor and Cochran 1967) before statistical analysis.

\section{Results and Discussion}

In perlite application, effects of smoke solutions on root and shoot lengths of grass pea were found to be statistically significant $(\mathrm{P}<0.01)$. The highest $(6.476 \mathrm{~cm})$ and the lowest $(4.476 \mathrm{~cm})$ root length were obtained from control and $50 \%$ smoke solution, respectively. The highest shoot length was observed $100 \%$ smoke solution $(4.669 \mathrm{~cm}$,). The lowest shoot length was noted as $1.807 \mathrm{~cm}$ in $50 \%$ smoke solution and $1.923 \mathrm{~cm}$ in $75 \%$ smoke solution. As a result, it was found similar results about effects on root and shoot lengths of smoke concentrations. In perlite application, root and shoot lenght were the highest in control and 100\% smoke solution, while they were the lowest in $50 \%$ smoke solution (Table 1).

After germination of grass pea seeds in petri, effects of smoke solutions on root and shoot lengths were examined, the differences among root and shoot lengths were found to be statistically significant. It was observed that the highest root length was in $25 \%, 75 \%$ and $100 \%$ smoke solutions (5.810, 6.089 and $5.840 \mathrm{~cm}$, respectively), whereas the lowest was in control solution as $3.742 \mathrm{~cm}$. Similarly, the highest shoot lengths were determined as $3.026 \mathrm{~cm}$ in $100 \%$ smoke solution (Table 2 ).

Table 1 Effects of different concentrations of sage smoke solutions on root and shoot lengths of grass pea in perlite environment

\begin{tabular}{l|ccccc}
\hline \multirow{2}{*}{ Concentration } & \multirow{2}{*}{ Control } & \multicolumn{4}{c}{ Smoke solutions (\%) } \\
\cline { 3 - 6 } & & 25 & 50 & 75 & 100 \\
\hline Root length $(\mathrm{cm})$ & $6.476^{\mathrm{a}}$ & $4.707^{\mathrm{ab}}$ & $4.476^{\mathrm{b}}$ & $4.830^{\mathrm{ab}}$ & $5.561^{\mathrm{ab}}$ \\
Shoot length $(\mathrm{cm})$ & $4.215^{\mathrm{ab}}$ & $2.623^{\mathrm{bc}}$ & $1.807^{\mathrm{c}}$ & $1.923^{\mathrm{c}}$ & $4.669^{\mathrm{a}}$ \\
\hline
\end{tabular}

Values shown in a line followed by different small letters are statistically different using Duncan's test at $1 \%$ level of significant 
Table 2 Effects of different concentrations of sage smoke solutions on root and shoot lenghts of grass pea in petri environment

\begin{tabular}{l|ccccc}
\hline \multirow{2}{*}{ Concentration } & \multirow{2}{*}{ Control } & \multicolumn{4}{c}{ Smoke solutions (\%) } \\
\cline { 3 - 6 } & & 25 & 50 & 75 & 100 \\
\hline Root lenght $(\mathrm{cm})$ & $3.742^{\mathrm{c}}$ & $5.810^{\mathrm{a}}$ & $4.962^{\mathrm{b}}$ & $6.089^{\mathrm{a}}$ & $5.840^{\mathrm{a}}$ \\
Shoot lenght $(\mathrm{cm})$ & $1.349^{\mathrm{c}}$ & $2.283^{\mathrm{bc}}$ & $1.743^{\mathrm{bc}}$ & $2.610^{\mathrm{ab}}$ & $3.026^{\mathrm{a}}$ \\
\hline
\end{tabular}

Values shown in a line followed by different small letters are statistically different using Duncan's test at $1 \%$ level of significant

Table 3 Effects of different concentrations of sage smoke solutions on seedling growth of grass pea in vitro condition

\begin{tabular}{l|ccccccc}
\hline \multicolumn{1}{c}{$\mathrm{P}$} & SF & RF & SL/P & FPW & NN/P & ERLBF & NLB/P \\
\hline MS & 93.3 & 33.3 & $5.43^{\mathrm{ab}}$ & $94.63^{\mathrm{b}}$ & $4.12^{\mathrm{ab}}$ & $55.0^{\mathrm{c}}$ & $1.33^{\mathrm{c}}$ \\
$25 \%$ & 85.0 & 0.0 & $8.35^{\mathrm{a}}$ & $128.48^{\mathrm{a}}$ & $4.41^{\mathrm{a}}$ & $60.0^{\mathrm{bc}}$ & $1.91^{\mathrm{bc}}$ \\
$50 \%$ & 95.0 & 15.0 & $7.23^{\mathrm{ab}}$ & $109.25^{\mathrm{ab}}$ & $2.25^{\mathrm{bc}}$ & $95.0^{\mathrm{a}}$ & $3.59^{\mathrm{a}}$ \\
$75 \%$ & 90.0 & 10.0 & $6.58^{\mathrm{ab}}$ & $86.91^{\mathrm{b}}$ & $1.94^{\mathrm{c}}$ & $90.0^{\mathrm{abc}}$ & $3.15^{\mathrm{ab}}$ \\
$100 \%$ & 90.0 & 10.0 & $5.00^{\mathrm{b}}$ & $87.65^{\mathrm{b}}$ & $3.90^{\mathrm{ab}}$ & $92.5^{\mathrm{ab}}$ & $2.96^{\mathrm{ab}}$ \\
\hline
\end{tabular}

P: Parameter, SF: Shoot formation (\%), RF: Root formation (\%), SL/P: Seedling length/Plant (cm), FPW: Fresh plant weight (mg), NN/P: Number of nod/Plant, ERLBF: Explant rate of lateral branch formation, NLB/P: Number of lateral branch/Plant (\%), Values shown in a column followed by different small letters are statistically different using Duncan's test at $1 \%$ level of significant

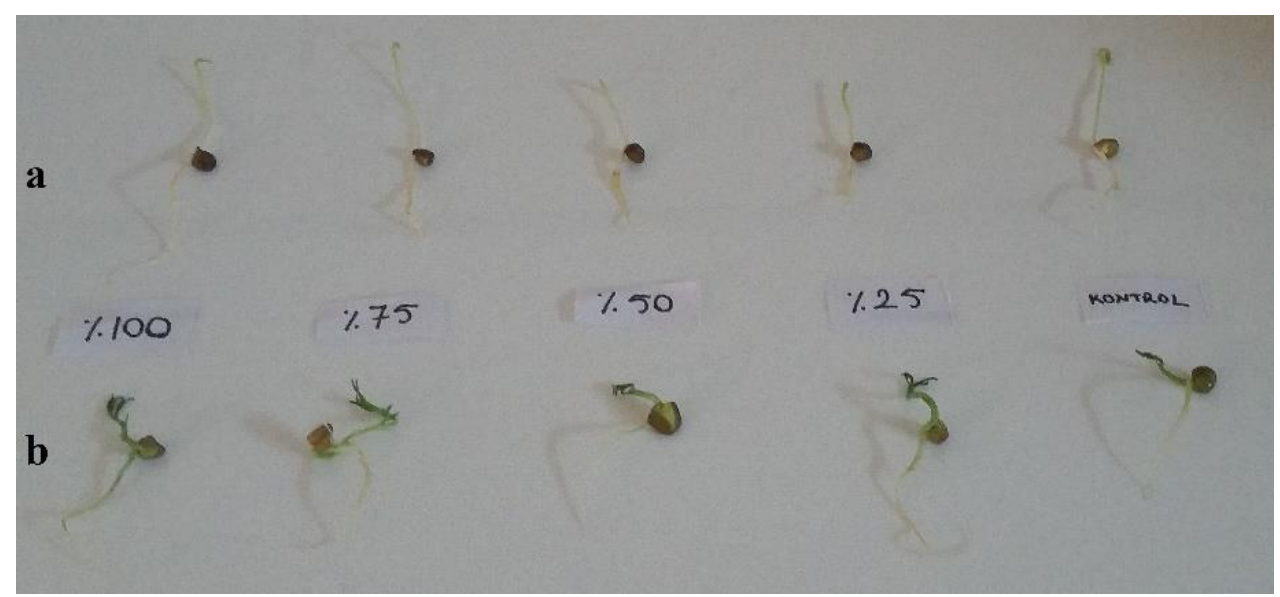

Figure 1 Root and shoot lengths of germinated grasspea seeds in perlite (a) and petri (b) applications

This study, effects of sage smoke solutions on root and shoot lengths of grass pea which have an important place in plant growth were examined. According to statistical analysis, $100 \%$ smoke solution was found to be more effective for root and shoot development for petri and perlite conditions (Figure 1).

There are many studies on smoke solution or smokederived compounds that can possibly be used in improving and promoting the growth of agricultural and horticultural crops such as red rice (Doherty and Cohn 2000), maize (Modi 2004), rice (Kulkarni et al., 2006), bean (Van Staden et al., 2006), okra (Kulkarni et al., 2007), tomato (Kulkarni et al., 2008), and onion (Kulkarni et al., 2010). Moreover, Chumpookam et al. (2012) reported that 10 different concentrations (from $0 \%$ to $10 \%, \mathrm{v} / \mathrm{v}$ ) of smoke solution derived dry rice straw (Oryza sativa cv. Japonica) promoted root and shoot lengths of papaya seedlings. Also, Ghebrehiwot et al. (2008) informed that smoke solution treated seeds produced significantly longer shoots or roots.

In vitro application, the effect of smoke solution on shoot and root formation from explant obtained from single nodal segments of grass pea was not significant. But the differences among shoot length, fresh plant weight, number of nod, explant rate of lateral branch formation and number of lateral branch under different smoke solutions were statistically significant (Table 3 ).
Shoot formation from nodal segments was observed in each treatment (Table 3). The highest percentage of shoot formation (95\%) was noted in 50\% concentration of smoke solution, but the lowest ( $85 \%$ ) was in $25 \%$ smoke solution. Kendir et al. (2009) were reported that shoot formation from MS medium containing BA (Benzyladenine) and NAA (Naphtalene avetic acid) was $93.33 \%$, but it was $100 \%$ under TDZ (Thidiazuron) concentrations. In the present study, root formation ranged from $33 \%$ to $0 \%$, in MS0 and 25\% smoke solution, respectively. However, it was revealed that there is statistically insignificant differences between applications for root and shoot formations. Root formation of grass pea in vitro was recorded as $78.7 \%$ on half-strength MS medium containing $2.85 \mu \mathrm{M}$ IAA (Indole acetic acid) application (Barik et al., 2005 ), as $76.56 \%$ on MS basal medium supplemented with $2 \mathrm{mg} / 1$ IBA (Barpete et al., 2014) and as $40 \%$ on half strength of MS basal medium containing $1.0 \mathrm{mg} / \mathrm{l} \mathrm{NAA}$ (Saha et al., 2015). Whereas, Kendir et al. (2009) notified that successful root formation was determined in MS medium containing NAA $(91.67 \%)$. But, Taylor and Staden (1998) notified the weak root growth in smoke solution applications. Likewise, in this study, root formations observed in 15 days'culture in vitro were found to be weak. 
Sparg et al. (2005) reported that seedling lengths obtained from 1:1000 smoke solution in Albuca pachychlamys and Tulbaghia violacea were higher than 1: 500 and 1:2000 applications, but Merwilla natalensis exhibited similar seedling lengths in all consentrations. Also, Kulkarni et al. (2008) tried concentrations of smokewater or butenolide solutions and observed higher plant height in tomato with 1:500 concentration of smoke solution compare to butenolide $(1 \mathrm{nM})$ and 1:2000 smoke solution. In our study, it was determined that the highest seedling length was $8.35 \mathrm{~cm}$ in $25 \%$ smoke application, also increasing smoke concentrations decreased seedling lengths. It was obtained $5.00 \mathrm{~cm}$ from $100 \%$ smoke concentration. Barik et al. (2005) reported that the highest shoot length in grass pea was $4.1 \mathrm{~cm}$ in MS medium containing BA and NAA. Kendir et al. (2009) were recorded that maximum shoot length $(6.23 \mathrm{~cm})$ on MS medium supplemented with BAP and NAA and increase in the concentration of BAP (6-Benzylaminopurine) to $4 \mathrm{mg} / \mathrm{l}$ had a negative effect on shoot growth of grass pea. Similarly, in vitro application in our study, increasing concentration of smoke solution had a negative effect on shoot growth. But smoke solutions were observed more effective than application of plant growth regulator in vitro. And, it was showed that explants didn't induced phenolic compounds in vitro. However, it was observed that increase in the concentration of smoke solution (over 50\%) had a positive effect on root and shoot growth in perlite and petri applications. This indicated that different concentrations of smoke solutions will have different effects in different environment on different species.

In addition, whereas the highest fresh plant weight $(128.48 \mathrm{mg})$ and number of nod per plant (4.41 plant/number) were obtained from $25 \%$ smoke solution, maximum explant rate of lateral branch formation (95\%) and number of lateral branch per plant (3.59 plant/number) were obtained from $50 \%$ smoke solution. Also, it was determined that there were no significant differences regarding explant rate of lateral branch formation and number of lateral branch at 50\%, 75\% and $100 \%$ smoke solution (Table 3). In addition high concentrations of smoke solutions exhibited negative effect on fresh plant weight. Similarly, Sparg et al. (2005) determined that 1:2000 smoke solution resulted in significantly greater seedling mass for both A. Pachychlamys and $T$. violacea than 1:1000 and 1:00 smoke solutions.

\section{Conclusion}

Speed germination and uniform seedling are highly crutial for effective production in agriculture. High yield and quality can only be guaranteed by the strong seedlings. Strong seedling is more resistant to biotic and abiotic stress factors and weed competition which are main problems of agriculture. Also, when there is lack of suitable conditions for germination in field applications, seeds is likely to be infected by some fungal pathogens into seedbed because of late germination. Roche et al. (1997) suggested that high concentrations of smoke solution may confer protection against predation and microbial attack to seeds and perhaps also to seedlings. It is commercially important that seeds in the field of agriculture have a high rate of healthy plant growth in addition to rapid and uniform growth. Therefore, smoke applications have the potential use so as to obtain healthy and vigorous seedling in cultivation of horticultural and field crops (Light and Van Staden 2004).For this reason, when it is made some priming applications to optimize seed germination by considering environmental conditions and changing features belonging to plant species (or varieties), it can be affected positively both directly seed germination and indirectly plant growth. Smoke solutions, one of the priming applications, have been studied by many researchers (Flematti et al., 2004, Van Staden et al., 2004, Light et al., 2005, Jain et al., 2006, Flematti et al., 2007, Kepczynski et al., 2010). According to previous studies, it was reported that concentrations of smoke, smoky water, active substance (butenolide etc.) had different effects on germination, shoot and root development for each species and variety, also shown effect of inhibitory or encouragement (Downes et al., 2010). However, many studies were reported that smoke or butenolide acts as gibberellic acid on germination (Nelson et al., 2009).

In our study, the effect of sage smoke solutions on germination of grass pea seeds was investigated. Statistically, in perlite application, although the highest root and shoot formations was determined in control and $100 \%$ smoke solutions, the lowest in $50 \%$ smoke solution. But, in petri dish application, the highest was observed in $75 \%$ and $100 \%$ smoke solution, the lowest in control.

In vitro application, smoke concentrations exhibited almost the same stimulatory and inhibitory effects on shoot and root formation. The highest shoot and root formations were observed in 50\% smoke solution (excluding control). Also, the highest explant rate of lateral branch formation, and number of lateral branch were obtained from $50 \%$ smoke solution. But, the highest shoot length, fresh plant weight, number of nod were observed in $25 \%$ smoke solution. When considered ex vitro, in vitro and other studies, it may be thought that different concentrations of smoke solutions have different effects in different environment on different species.

As a result, it was found that sage smoke solution had effective on shoot and root developments of grass pea seeds. Also this effect was determined to changed depending on the concentrations.

\section{References}

Abd El-Moneim AM, Van Dorrestein B, Baum M, Mulugeta W. 2012. Improving the Nutritional Quality and Yield Potential of Grasspea (Lathyrus Sativus L.). Food and Nutrition Bulletin, 21:(4).

Barik DP, Mohapatra U, Chand PK. 2005. High frequency in vitro regeneration of Lathyrus sativus L. Biologia Plantarum, 49: 637-639.

Barpete S, Khawar KM, Özcan S. 2014. Differential competence for in vitro adventitous rooting of grass pea (Lathyrus sativus L.). Plant Cell Tiss Organ Cult., 119: 39-50.

Basaran U, Mut H, Gulumser E, Dogrusoz MC. 2016. Evaluation of Turkish grass pea (Lathyrus sativus L.) collections for it agronomic characters with a special reference to ODAP content. Legume Research-An International Journal, 39(6): 876-882.

Campbell CG. 1997. Grass pea (Lathyrus sativusL.). Promoting the conservation and use of underutilized and neglected crops. International Plant Genetic Resources Institute, Rome, Italy. 
Chumpookam J, Lin HL, Shiesh CC. 2012. Effect of Smokewater on Seed Germination and Seedling Growth of Papaya (Carica papaya cv.Tainung No.2). Hortscience, 47(6):741744.

Croft AM, Pang ECK, Taylor PWJ. 1999. Molecular analysis of Lathyrus sativus L.(grasspea) and related Lathyrus species. Euphytica, 107(3): 167-176.

De Lange JH, Boucher C. 1990. Autecological studies on Audouinia capitata (Bruniaceae). I. Plant-derived smoke as a seed germination cue. South African Journal of Botany, 56(6): 700-703.

Dixon KW, Merritt DJ, Flematti GR, Ghisalberti EL. 2009. Karrikinolide: a phytoreactive compound derived from smoke with applications in horticulture, ecological restoration, and agriculture. Acta Hortic (in press).

Doherty LC, Cohn MA. 2000. Seed dormancy in red rice (Oryza sativa). XI. Commercial liquid smoke elicits germination. Seed Sci.Res., 10:415-421.

Downes KS, Lamont BB, Light ME, van Staden J. 2010. The fire ephemeral Tersonia cyathiflora (Gyrostemonaceae) germinates in response to smoke but not the butenolide 3methyl-2H-furo[2,3-c]pyran-2-one. Annals of Botany, 106(2), 381-384.

Flematti GR, Ghisalberti EL, Dixon KW and Trengove RD. 2004. A compound from smoke that promotes seed germination. Science, 305: 977.

Flematti GR, Goddard-Borger ED, Merritt DJ, Ghisalberti EL, Dixon KW, Trengove RD. 2007. Preparation of 2H-furo[2,3c]pyran-2-one derivativesand evaluation of their germination-promoting activity. - Journal ofAgricultural and Food Chemistry, 55: 2189-2194.

Ghebrehiwot HM, Kulkarni MG, Kirkman KP, Van Staden J. 2012. Smoke and heat: influence on seedling emergence from the germinable soil seed bank of mesic grassland in South Africa. Plant Growth Regul., 66:119-127.

ISTA. 2004. International Rules for Seed Testing Edition. Zurich, Switzerland.

Jain N, Kulkarni MG, van Staden J. 2006. A butenolide, isolated from smoke,can overcome the detrimental weffects of extreme tepratures during tomatoseed germination. - Plant Growth Regulator, 49, 263-267.

Kendir H, Sahin-Demirbag N, Khawar KM, Özcan S. 2009. In vitro plant regeneration from turkish grasspea (Lathyrus Sativus L.) using 1mmature zygotic embryo explant.Biotechnology \& Biotechnological Equipment, 23:2, 1177 1180.

Kepczynski J, Cembrowska D, Van Staden J. 2010. Releasing primary dormancyin Avena fatua L. caryopses by smokederived butenolide. Plant Growth Regulation, 62: 85-91.

Kulkarni MG, Ascough GD, Van Staden J. 2007. Effects of foliar applications of smokewater and a smoke-isolated butenolide on seedling growth of okra and tomato. HortScience, 42:179182.

Kulkarni MG, Ascough GD, Van Staden J. 2008. Smoke-water and a smoke-isolated butenolide improve growth and yield of tomatoes under greenhouse conditions. HortTechnology, 18:449-454.
Kulkarni MG, Ascough GD, Verschaeve L, Baeten K, Arruda MP, Van Staden J. 2010. Effect of smoke-water and a smokeisolated butenolide on the growth and genotoxicity of commercial onion. Sci. Hort., 124: 434-439.

Kulkarni MG, Sparg SG, Light ME, van Staden J. 2006. Stimulation of Rice (Oryza sativa L.) seedling vigour by smoke-water and butenolide. Journal of Agronomy and Crop Science, 192 (5): 395-398.

Kumar S, Bejiga G, Ahmed S, Nakkoul H, Sarker A. 2011. Genetic improvement of grass pea for low neurotoxin (bODAP) content. Food and Chemical Toxicology, 49 (3): 589600.

Light ME, Burger BV, van Staden J. 2005. Formation of a seed germinationpromoter from carbonhydrates and amino acids. Journal of Agricultural and Food Chemistry, 53 (15): 59365942.

Light ME, Van Staden J. 2004. The potential of smoke in seed technology. S. Afr. J. Bot., 70: 97-101.

Modi AT. 2004. Short-term preservation of maize landrace seed and taro propagules using indigenous storage methods. S. Afr. J. Bot., 70: 16-23.

Murashige T, Skoog F. 1962. A revised medium for rapid growth and bioassays with tobacco tissue cul- tures. Physiologia Plantarum, 15: 473-497.

Nelson DC, Riseborough JA, Flematti GR. 2009. Karrikins discovered in smoke trigger Arabidopsis seed germination by a mechanism requiring gibberellic acid synthesis and light. Plant Physiology, 149: 863-873.

Roche S, Koch JM, Dixon KW. 1997. Smoke enhanced seed germination for mine rehabilitation in the southwest of Western Australia. Restor. Ecol., 5: 191-203.

Saha P, Afrin M, Mohiuddin AKM, Shohael AM. 2015. In vitro Regeneration of Grass Pea (Lathyrus sativus L.). Jahangirnagar University J. Biol. Sci., 4(2): 1-8.

Snedecor GW, Cochran WG. 1967. Statistical Methods. The Iowa State University.

Sparg SG, Kulkarni MG, Light ME, Van Staden J. 2005. Improving seedling vigour of indigenous medicinal plants with smoke. Bioresource Technology, 96: 1323-1330.

Steinbach HS, Benech-Arnold R, Sanchez RA. 1997. Hormonal regulation of dormancy in developing sorghum seeds.Plant Physiology, 113: 149-154.

Subaş1 Ü, Güvensen A. 2010. Seed germination studies on rare endemic Salvia smyrnaea Boiss. (Lamiaceae). Biological Diversity and Conservation, 3: 126-132.

Taylor JLS, Van Staden J. 1998. Plant-derived smoke solutions stimulate the growth of Lycopersicon esculentum roots in vitro. Plant Growth Regulation, 26: 77-83.

Van Staden J, Jager AK, Light ME, Burger BVI. 2004. solation of the major germination cue from plant-derived smoke. S Afr J Bot., 70: 654-659.

Van Staden J, Sparg SG, Kulkarni MG, Light ME. 2006. Post germination effects of the smoke-derived compound 3methyl-2Hfuro[2,3-c]pyran-2-one, and its potential as a preconditioning agent. Field Crops Res., 98: 98-105. 